down their arms to return to their studies. Trauma-healing workshops were conducted to prepare the entire university community for resumption of classes. We planned a trimester academic year, in which one-third of total enrollment would be engaged in the countryside in any given trimester. The country was divided into zones. For example, agriculture students would work with farmers in the target zone, learning from them and teaching new techniques of modern agriculture. Engineering students would design and construct nonmechanical irrigation systems, sink wells for safe drinking water, and build local houses. Business students would help farmers in setting up bookkeeping to determine their profits and losses, as well as how best to market their produce. Medical students would inoculate everyone against communicable diseases. Education students would conduct mass literacy programs so that, by the end of the trimester, everyone in the target zone would be literate. Pharmacy, botany, and chemistry students would team up with herbalists to study the chemical properties of herbs used in treating diseases in order to produce new drugs. All students would participate in food production and mass literacy.

The following were to be achieved in three to five years: (1) make the university a catalyst for transforming Liberiathe entire society becoming its laboratories/classrooms;

(2) empower students to create their own social knowledge and actively participate in defining and creating their future; (3) make Liberia self-sufficient in food production; (4) wipe out illiteracy; and (5) improve the quality of life of the people.

The program could not be implemented due to the war. By April 1996, enrollment was 5,250, when new factional fighting broke out and the university was looted of all equipment and furniture. It is attempting to rehabilitate itself again - with faculty and students scattered across West Africa.

The University of Liberia's case is not entirely unique, as other universities in Africa, and Central and Eastern Europe have been similarly affected. Yet there is no outrage from the academic community about the plight of these institutions and the societies they serve. If inaction is the result of lack of information, then an alert network system needs to be established that would sound an alarm when a university is threatened or comes under attack. Following breakdown of a university, a consortium of universities in the developed world could be organized to work with foundations and donor governments for its restoration. Since the university is so vital to modern society - particularly its library-it needs to be treated as a museum to be protected by UNESCO, and an international convention should be drawn up for its protection.

\section{A Southeast Asian Initiative in Higher Education SEAMEO-RIHED}

\section{Tong-In Wongsothorn}

Tong-In Wongsothorn is director of RIHED. Address: 5th floor, Ministry of University Affairs Building, 328 Sri Ayutthaya Rd., Bangkok 10400, Thailand. Fax: 662-644-5421.

WHAT IS SEAMEO-RIHED?

7 he history of RIHED dates back to 1959 when the 1 Regional Institute of Higher Education and Development (RIHED) was conceived jointly by UNESCO and the International Association of Universities (IAU), in collaboration with the Ford Foundation. It was not officially founded, however, until 1970, with seven member statesnamely, Cambodia, Indonesia, Laos, Malaysia, Singapore, Thailand, and Vietnam. In 1985 RIHED became inactive due to some of the member countries being unable to participate fully and the decision was then taken to reconstitute RIHED under the SEAMEO umbrella.

The Southeast Asian Ministers of Education Organization (SEAMEO) was established in 1965 in order to hasten the development of the region through regional cooperation in education, science, and culture. In 1993 RIHED, now based in Bangkok, Thailand, became the 12th SEAMEO center, with the mission to promote cooperation for the development of higher education in the region. The original acronym RIHED-from the period when it functioned as a regional institute in Singaporewas retained; however, it is now known as the Regional Centre for Higher Education and Development.

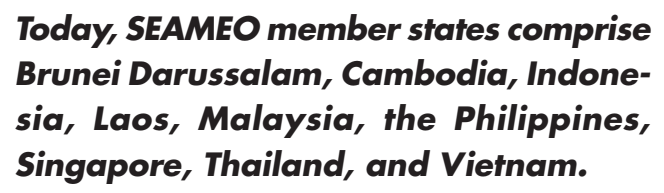

Today, SEAMEO member states comprise Brunei Darussalam, Cambodia, Indonesia, Laos, Malaysia, the Philippines, Singapore, Thailand, and Vietnam. SEAMEO's associate member countries are: Australia, Canada, France, Germany, the Netherlands, and New Zealand.

What ARE THE ACtivities of THE SEAMEO-RIHED? To fulfill its mission RIHED's functions focus on training, research, information dissemination, and the promotion of 
collaboration and linkages. RIHED is committed to tackling issues of common concern for SEAMEO member countries and not only keeps pace with regional and international developments but has to be one step ahead — anticipating and acting accordingly. In practice the activities take the form of:

- training for the personnel of higher education institutes in the region, with RIHED acting as the facilitator;

- information exchange through the arrangement of conferences, seminars, and workshops with the cooperation from the relevant concerned agency, government and/or centre;

- information dissemination through conducting research and publishing the findings, publishing the conference and seminar proceedings and recommendations, and by publishing and distributing the quarterly newsletter, the RIHED Bulletin; and

- promotion of collaboration and linkages.

To maximize the benefits of RIHED's activities, and at the same time to strengthen regional cooperation, many activities are carried out within regional groupings like EAGA (East ASEAN Growth Area), GMS (Greater Mekong Subregion), and IMT-GT (Indonesia-MalaysiaThailand Growth Triangle). Cooperation with the French government is particularly strong with a commitment to providing quality engineering and technology educationespecially for the Indochina countries. So the promotion of collaboration and linkage is a continuous process between RIHED and various partners. For example RIHED also works closely with many concerned agencies-like UNESCO PROAP; with university affiliations-like AUAP, ASAIHL and IMT-GT UNINET; with universities on an individual basis, with education ministries in the region; and with other SEAMEO centers-notably SEARCA and INNOTECH in the Philippines and RECSAM in Malaysia.

\section{How IS SEAMEO-RIHED FUNDED?}

RIHED is supported by the Royal Thai government. It receives donations from associate member countries and concerned agencies, and has an endowment fund. But in order to increase its scope of activities and to become more self-reliant, training on a fee-paying basis has been initiated. RIHED is a nonprofit organization and as such any earned income is channeled into further development of projects. Close collaboration with concerned agencies, other centers, and educational institutions within the region ensures optimum utilization of resources and facili- ties, while avoiding any duplication of efforts or waste of funds.

\section{The Future AND SEAMEO-RIHED}

RIHED will continue to strive to be a regional center of excellence in the area of higher education, research, and training. Specific programs include a higher educational management program, a higher education research program, and an information and documentation program. The promotion of human resource development remains a major focus of the center's activities. Increased information dissemination will be achieved through the establishment of an electronic library and the launching of a new publication-the Southeast Asia Higher Education Review.

Information on RIHED can be accessed at its web site, located at: http:mismua.go.th/rihed/rihed.html

\section{Boston College Program Sponsors Readings Series on Higher Education}

The Garland Readings Series in Higher Education will be published in mid-1997. This series of seven volumes, under the general editorship of Philip G. Altbach, includes books on a range of key topics in higher education. All of the books include carefully selected readings on aspects of higher education along with a introduction by the editor of each volume. The series will be available from Garland Publishing, Inc. 1000A Sherman Ave., Hamden, CT 06514. The series includes volumes edited by faculty at Boston College as well as others. The following books are included in the series:

1. Issues in Catholic Higher Education, Joseph O'Keefe, S.J., associate professor of educational administration, Boston College

2. Latin American Higher Education, Lewis Tyler, director, Latin American Scholarship Program of American Universities, Harvard University and colleagues

3. Graduate Education, Maresi Nerad, associate dean, Graduate Division, University of California, Berkeley.

4. Student Development, Karen Arnold, associate professor of higher education, Boston College

5. Organization and Administration of Higher Education, Ted I. K. Youn, associate professor of higher education, Boston College

6. European Higher Education, Peter Darvas, Soros Foundation

7. The Academic Profession, Philip Altbach, professor of higher education, Boston College, and Dr. Martin Finkelstein, professor of higher education, Seton Hall University 